\title{
Leaf Pigment, Phenolic Content, and Production of Green Shallot of Five Different Shallot Varieties
}

\author{
DOI: $10.18196 /$ pt.v9i1.8045
}

\author{
Fiadini Putri ${ }^{1}$, Sandra Arifin Aziz ${ }^{2 *}$, Nuri Andarwulan ${ }^{3}$, Maya Melati ${ }^{2}$, Suwarto ${ }^{2}$ \\ ${ }^{1}$ Study Program of Agronomy and Horticulture, Department of Agronomy and Horticulture, Graduate School, \\ IPB University, West Java, 16680, Indonesia \\ ${ }^{2}$ Department of Agronomy and Horticulture, IPB University, Bogor, West Java, 16680, Indonesia \\ ${ }^{3}$ Department of Food Science and Technology, IPB University, Bogor, West Java, 16680, Indonesia \\ *Corresponding author, email: sandraaziz@apps.ipb.ac.id
}

\begin{abstract}
Five shallot varieties namely 'Bauji', 'Bantaeng', 'Tuk Tuk', 'Rubaru', and 'Palasa' were examined for their leaf pigment, total phenolic content, leaf tissue nutrient analysis, and green shallot production. The experiment was conducted in in Cikabayan greenhouse, IPB University, Dermaga, Bogor, arranged in a randomized complete block design with single factor (variety) and three replications. The observations were carried out three times in the maximum vegetative period, consisting of 20, 30, and 40 days after planting. The result showed that' Palasa' had the highest leaf pigment content, such as chlorophyll a, chlorophyll b, total chlorophyll, and carotenoid, while the anthocyanin content fluctuated between the varieties and observation times. 'Palasa' also had the highest sulfur content in the leaf tissues. On the contrary, 'Palasa' had the lowest production compared to other the varieties. Meanwhile, 'Bantaeng' had the highest green shallot production, total nitrogen, and total phosphorus content in the leaf tissues. Total phenolic content fluctuated in the five varieties and observation times. The highest total phenolic content was in 'Tuk Tuk', observed 20 days after planting. The principal component analysis (PCA) showed that the five shallot varieties formed three clusters. The first was 'Palasa', the second cluster was 'Bauji', 'Tuk Tuk', and 'Rubaru', while the third cluster was 'Bantaeng.' Palasa' had the highest content of leaf pigment, while Bantaeng had the highest leaf production. Leaf pigment and total phenolic content changed along with the increasing plant age in all varieties.
\end{abstract}

Keywords: Anthocyanin, Carotenoid, Chlorophyll, Leaf tissue, PCA

\section{ABSTRAK}

Lima varietas bawang merah yaitu Bauji, 'Bantaeng', 'Tuk Tuk', 'Rubaru' dan 'Palasa' digunakan dalam percobaan untuk mengetahui kandungan klorofil, fenol total dan produksi daun bawang merah. Percobaan dilaksanakan menggunakan Rancangan Kelompok Lengkap Teracak (RKLT) dengan satu faktor dan tiga ulangan bertempat di rumah kaca Cikabayan, kampus IPB, Dramaga, Bogor. Pengambilan data dilakukan sebanyak tiga kali yaitu pada 20, 30 dan 40 hari setelah tanam (HST). Hasil percobaan menunjukkan bahwa varietas 'Palasa' memiliki kadar klorofil a, klorofil b, klorofil total dan karotenoid yang tertinggi, sementara antosianin berfluktuasi pada semua waktu pengamatan dan varietas yang digunakan. 'Palasa' juga memiliki kandungan sulfur total daun yang tertinggi, namun demikian 'Palasa' memiliki produksi daun yang terendah dibandingkan varietas yang lain. 'Bantaeng' memiliki produksi daun yang tertinggi, demikian juga dengan kadar nitrogen dan fosfor total pada jaringan daun. Total fenol pada daun bawang merah berfluktuasi pada setiap varietas dan waktu pengamatan. Total fenol tertinggi dimiliki oleh 'Tuk Tuk' pada 20 HST. Analisis komponen utama menunjukkan bahwa ke lima varietas yang digunakan dapat dikelompokkan menjadi tiga kelompok berdasar kandungan pigmen, hara dan produksi daun. Kelompok pertama adalah 'Palasa' dan 'Rubaru', kedua adalah 'Tuk Tuk' dan Bauji dan ketiga adalah 'Bantaeng.' 'Palasa' memiliki kadar pigmen daun yang tertinggi diantara varietas yang digunakan sementara 'Bantaeng' memiliki produksi daun yang tertinggi. Kadar pigmen dan total flavonoid berubah seiring dengan pertambahan umur tanaman pada seluruh varietas bawang merah yang digunakan.

Kata Kunci: Analisis komponen utama, Jaringan daun, Klorofil, antosianin, karotenoid

\section{INTRODUCTION}

Vegetables are essential in the human diet in providing balanced nutrient and minerals. They are known to be beneficial to the human body in preventing or treating diseases and improving physiological performance beyond adequate nutritional effects in a way to either improved stage of health and the reduced risk of disease (Ramya \& Patel, 2019). Shallot is a species of the Alliaceae family considered a valuable vegetable crop in Indonesia. Other than being used as vegetables and spices, shallot has been used by Indonesian people for its traditional medical properties and believed to prevent numbers of diseases that attributed to its biochemical content (Balitbangtan, 2007). Shallot plant is mostly cultivated for its bulbs, while the leaves are not commonly consumed, unlike onion 
whose leaves are consumed, which are called green onions or scallions. Green onion is a vital export commodity for several countries, such as Holland and Egypt. It has been used for vegetables and spices worldwide for ages (El-Hamd et al., 2016). Meanwhile, for limited consumption, green shallot in Indonesia is sold at a high price. It is commonly used in Chinese cuisine and some local dishes.

Planting shallots have a high risk, many challenges, and obstacles in its cultivation cycle, mainly the attack of organisms causing disease in plants, such as pest and pathogen that result in the harvest loss, especially in the off-season. Shallot is mostly grown for 60 to 70 days at the field to get the bulbs, while green shallot is usually harvested at 30-40 days after planting (DAP). Green shallots are harvested when the leaves remain green, and the bulb is not fully formed. Shorter time to harvest shallot plants will help the farmer optimize its land utilization (Dharma, 2016).

Some leaf pigments also are known as secondary metabolites that have benefits in human diets. Dark leaf pigments, such as anthocyanin and carotenoids, are believed as bioactive agents against some diseases in human. They are able to fight some viruses, bacteria, pathogens, tumor cells, and even cancers. These pigments protect the cell, functioning as a free radical extinguishers that inhibit the cancer cell progression (Upadhyay, 2018). Fruit and vegetable intake are suggested in the human daily diet. They are rich in the phenolic compounds that thought to be responsible for human health by reducing the chronic disease risk (Gutiérrez-Grijalva et al., 2016).

The exact time to harvest leafy vegetables needs to be determined to get the best quality. Delay in harvesting leafy vegetables might increase the vegetable biomass. However, it will change the chemical content of the leaf, degrading the vegetable quality and affecting the shelf-life. Total phenolic content of T. triangulare leaf decreased by $11.76 \%$ in winter and $13.69 \%$ in summer when the harvesting time was delayed from 30 days to 60 days (Brasileiro et al., 2015)

There are many varieties of shallot that have been released by the government and private companies in Indonesia. The varieties could be chosen by the farmer according to their soil type, environment, and season. Choosing the right variety will improve the yield and quality of shallot. Farmers in East Java prefer planting shallot varieties such as 'Rubaru' from Sumenep and Bauji (Baswarsiati et al., 2015). Meanwhile, in Sulawesi Island, there are varieties of 'Bantaeng' from South Sulawesi and 'Palasa' from Central Sulawesi. 'Bantaeng' variety is recognized to be similar to shallot varieties from Sumatra and Java. However, it is adapting in a local environment and growing with its local specialty (Sari et al., 2017). Meanwhile, 'Palasa' variety is known to be used for fried shallot. Shallot could be planted from its seed called true seed shallot (TSS). One of the varieties propagated from seeds is 'Tuk Tuk' variety that was released by East-West Seed Indonesia company. 'Tuk Tuk' could be planted directly or used to produce a mini bulb and replanted to get the bulb for consumption (Balitbangtan, 2015). Most of the shallot varieties released and research in shallot focus on the bulb production, while there is still limited information about the green shallot production and quality. This research was conducted to gain more information about leaf shallot pigment, leaf total phenolic content, and leaf production at different observation time, aiming to get a better quality of green shallot from five different varieties.

\section{MATERIALS AND METHODS}

The experiment was carried out from November to December 2018 in Cikabayan greenhouse, IPB University Bogor, Indonesia. Five shallot varieties, 
including 'Bauji', 'Bantaeng', 'Tuk Tuk', 'Rubaru', and 'Palasa' were planted one bulb per polybag inside the greenhouse with mixed media of soil, rice hull, and compost $(1: 1: 1 \mathrm{v} / \mathrm{v})$. The experiment was arranged in a randomized completed block design with three replications. The shallot leaf was taken in 20, 30, and 40 days after plamting (DAP) for the analysis of chlorophyll, anthocyanin content, carotenoid, total phenolics content, and production.

Chlorophyll a, chlorophyll b, total chlorophyll, anthocyanin, and carotenoids of shallot leaf were determined using the method described by Sims and Gamon (2002) with modification. Fresh leaf (200 mg) was extracted in $2 \mathrm{ml}$ of acetone and centrifuge (6000 rpm for 10 minutes). The supernatant $(1 \mathrm{ml})$ was taken and mixed with $3 \mathrm{ml}$ acetone. The absorbance of the extracts was measured at 470, 537, 647, and $663 \mathrm{~nm}$ using spectrophotometer Shimadzu UV-1820.

Folin-Ciocalteau method was used to determine the total phenolic content of the plant extracts using gallic acid as standard or Gallic acid equivalent (Lombardo et al., 2018) (Fuentealba et al., 2017) with slight modification. The whole part of the green leaf was collected, cleaned, trimmed then immediately stored in $-20^{\circ} \mathrm{C}$ then lyophilized using freeze dryer (FreeZone 61 Console Freeze Dry System, Labconco, Kansas City, MO). The result was then ground into powder and kept at a temperature of $-20^{\circ} \mathrm{C}$ until it was used. The leaf powder $(100 \mathrm{mg})$ was extracted in the microtube with $5 \mathrm{ml}$ of $80 \%$ ethanol for 48 hours. The microtube was centrifuged, and $0.5 \mathrm{ml}$ of supernatant was taken and mixed with $3 \mathrm{ml}$ of distilled water and $0.5 \mathrm{ml}$ of $50 \%$ Folin Ciocalteu, which was then incubated for 5 minutes. The solution was added with $1 \mathrm{ml}$ of $7 \% \mathrm{Na}_{2} \mathrm{CO}_{3}$. It was kept in the dark for 60 minutes to obtain an absorbance at $725 \mathrm{~nm}$. Total phenolic content was measured in 20,30 , and 40 DAP to know the fluctuation during the harvest time. The green shallot production was determined based on total fresh weight of shallot plant (ton ha1). Plant nutrient analysis for nitrogen, phosphorous, and potassium in shallot leaves were carried out following the method by Eviati \& Sulaeman (2009).

The data obtained were analyzed using analysis of variance and continued with Duncan's multiple range test with a 95\% confidence level using SPSS 22.0. Relationships between variables were observed through Principal Component Analysis using XLSTAT 2014.5.03. and R program for a hierarchical heat map.

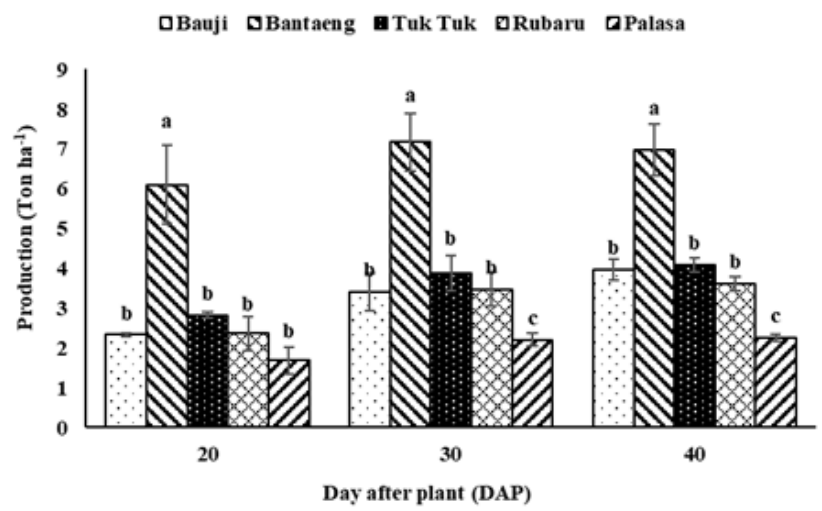

Figure 1. The production of green shallot from five varieties in 20, 30 and 40 DAP

\section{RESULTS AND DISCUSSION}

Data were obtained in 20, 30, and 40 DAP for green shallot, which is commonly harvested in its maximum vegetative period. The production of green shallot was calculated from the whole part of fresh shallot weight (green part, white part, and root) since it is sold in the whole part plant in the market (Putri et al., 2020). According to Figure 1, 'Bantaeng' variety had the highest production compared to Bauji, 'Tuk Tuk', 'Rubaru', and 'Palasa' varieties, while 'Palasa' variety had the lowest production. At 20 DAP, 'Palasa' variety only reached $27.45 \%$ of the production of 'Bantaeng' variety, while at $30 \mathrm{DAP}$, it only produced about $30.82 \%$ of 'Bantaeng' production, and at 40 DAP, 
Table 1. Chlorophyll a, chlorophyll b, total chlorophyll (a+b), anthocyanin content and carotenoid content of leaf from five different varieties at 20,30 and 40 DAP

\begin{tabular}{|c|c|c|c|c|c|}
\hline \multirow[t]{2}{*}{ Variety } & $\begin{array}{l}\text { Chlorophyll a } \\
\text { (mg g }{ }^{-1} \text { FW) }\end{array}$ & $\begin{array}{c}\text { Chlorophyll b } \\
\left(\mathrm{mg} \mathrm{g}^{-1} \mathrm{FW}\right)\end{array}$ & $\begin{array}{l}\text { Total Chlorophyll } a+b \\
\left(\mathrm{mg} \mathrm{g}^{-1} \mathrm{FW}\right)\end{array}$ & $\begin{array}{l}\text { Anthocyanin } \\
\left(\mathrm{mg} \mathrm{g}^{-1} \mathrm{FW}\right)\end{array}$ & $\begin{array}{l}\text { Carotenoid } \\
\left(\mathrm{mg} \mathrm{g}^{-1} \mathrm{FW}\right)\end{array}$ \\
\hline & \multicolumn{5}{|c|}{20 DAP } \\
\hline Bauji & $0.607 \pm 0.015 b c$ & $0.247 \pm 0.002 b c$ & $0.853 \pm 0.017 b$ & $0.032 \pm 0.003 b$ & $0.200 \pm 0.006 b$ \\
\hline 'Bantaeng' & $0.583 \pm 0.027 c$ & $0.240 \pm 0.013 c$ & $0.823 \pm 0.039 c$ & $0.027 \pm 0.001 \mathrm{~b}$ & $0.194 \pm 0.009 b$ \\
\hline 'Tuk Tuk' & $0.682 \pm 0.085 b$ & $0.274 \pm 0.035 b c$ & $0.956 \pm 0.012 b c$ & $0.031 \pm 0.004 b$ & $0.220 \pm 0.025 b$ \\
\hline 'Rubaru' & $0.702 \pm 0.062 b$ & $0.281 \pm 0.019 b$ & $0.983 \pm 0.081 b$ & $0.033 \pm 0.003 a b$ & $0.223 \pm 0.018 b$ \\
\hline \multirow[t]{2}{*}{ 'Palasa' } & $0.918 \pm 0.024 \mathrm{a}$ & $0.352 \pm 0.007 a$ & $1.269 \pm 0.031 \mathrm{a}$ & $0.039 \pm 0.002 \mathrm{a}$ & $0.284 \pm 0.003 \mathrm{a}$ \\
\hline & \multicolumn{5}{|c|}{30 DAP } \\
\hline Bauji & $0.651 \pm 0.026 b$ & $0.255 \pm 0.009 b$ & $0.906 \pm 0.035 b$ & $0.023 \pm 0.001 \mathrm{a}$ & $0.203 \pm 0.007 b c$ \\
\hline 'Bantaeng' & $0.635 \pm 0.046 b$ & $0.266 \pm 0.018 b$ & $0.901 \pm 0.065 b$ & $0.027 \pm 0.001 \mathrm{a}$ & $0.199 \pm 0.013 b c$ \\
\hline 'Tuk Tuk' & $0.654 \pm 0.054 b$ & $0.260 \pm 0.017 b$ & $0.914 \pm 0.071 \mathrm{~b}$ & $0.023 \pm 0.002 \mathrm{a}$ & $0.194 \pm 0.013 c$ \\
\hline 'Rubaru' & $0.702 \pm 0.024 b$ & $0.271 \pm 0.009 b$ & $0.973 \pm 0.034 b$ & $0.024 \pm 0.003 a$ & $0.216 \pm 0.008 b$ \\
\hline \multirow[t]{2}{*}{ 'Palasa' } & $0.837 \pm 0.028 a$ & $0.322 \pm 0.012 \mathrm{a}$ & $1.159 \pm 0.040 \mathrm{a}$ & $0.026 \pm 0.002 \mathrm{a}$ & $0.246 \pm 0.009 a$ \\
\hline & \multicolumn{5}{|c|}{40 DAP } \\
\hline Bauji & $0.610 \pm 0.005 b$ & $0.260 \pm 0.006 b$ & $0.869 \pm 0.036 b$ & $0.046 \pm 0.009 a$ & $0.200 \pm 0.007 a b$ \\
\hline 'Bantaeng' & $0.471 \pm 0.043 c$ & $0.200 \pm 0.009 c$ & $0.671 \pm 0.008 c$ & $0.019 \pm 0.007 c$ & $0.158 \pm 0.008 d$ \\
\hline 'Tuk Tuk' & $0.610 \pm 0.015 b$ & $0.243 \pm 0.025 b$ & $0.853 \pm 0.036 b$ & $0.027 \pm 0.004 b c$ & $0.182 \pm 0.008 b c$ \\
\hline 'Rubaru' & $0.561 \pm 0.011 b$ & $0.232 \pm 0.009 b$ & $0.794 \pm 0.085 b$ & $0.027 \pm 0.007 b c$ & $0.175 \pm 0.020 \mathrm{~cd}$ \\
\hline 'Palasa' & $0.744 \pm 0.038 a$ & $0.296 \pm 0.011 a$ & $1.039 \pm 0.059 a$ & $0.032 \pm 0.009 \mathrm{~b}$ & $0.216 \pm 0.011 \mathrm{a}$ \\
\hline
\end{tabular}

its production reached $32.23 \%$ of that of 'Bantaeng'. Different varieties respond differently to the same growth environment at the greenhouse. The interaction between genotype of each variety and environment condition related to the cultivation technique will result in different yields and quality (Sekara et al., 2017). In the greenhouse, 'Palasa' variety showed poor growth in the vegetative phase, especially when compared to 'Bantaeng' variety.

The chlorophyll measurement was conducted to examine the photosynthesis performance in the five varieties tested. Chlorophyll is photosynthesis pigment that has a function in harvesting light energy. The fresh weight-based chlorophyll measurement method showed that in overall, 'Bantaeng' variety had the lowest chlorophyll a, chlorophyll b and total chlorophyll (chlorophyll $\mathrm{a}+\mathrm{b})$. On the contrary, the highest chlorophyll content was observed in 'Palasa' variety (Table 1). At 30 DAP, which is considered as the shallot vegetative maximum growth time, 'Palasa' variety had 31.81\% higher chlorophyll a, compared to 'Bantaeng' variety. 'Palasa' variety also had the highest chlorophyll b content, which was $23.85 \%$ higher compared to 'Tuk Tuk', which had the lowest content of chlorophyll b even though there were no significant differences between Bauji, 'Bantaeng', 'Tuk Tuk' and 'Rubaru'. Chlorophyll content commonly increased from 20 to 30 DAP, then slightly started to decrease at 40 DAP. Chlorophyll content increased with the increasing plant age and maturity.

The older plant has higher chlorophyll content than the young plant (Kamble et al., 2015). At the time shallot plant starts to enter the bulb filling phase, the leaf chlorophyll content starts to decrease, passing the maximum vegetative growth. Chlorophyll breakdown that caused the lower chlorophyll content in the leaf is one of the obvious signs for leaf senescence. When senescence begins to occur in the leaves, the appearance of a yellowish 
color on the old leaves indicates that the plant is starting to terminate its growth, entering the next phase, such as bulb filling or fruit ripening. The catabolite resuting from chlorophyll degradation accumulate in the vacuole cells of senescence leaves (Kuai et al., 2018). The chlorophyll degradation will appear as the increase in plant age until the harvesting time. The harvesting times in shallot is mostly calculated for the bulb harvesting. Meanwhile, the leaf or green shallot harvesting is usually conducted when the plant still in maximum vegetative phase to avoid the degradation of leaf green color because it will reduce the product quality. Besides as a sign for leaf senescence, the chlorophyll degradation is also indicating the health status of the plant. (Pavlovi et al., 2014).

Different varieties of shallot had different chlorophyll content. 'Bantaeng' variety, which had the highest production and bigger leaf, showed the lowest chlorophyll content compared to 'Palasa' variety, which had the lowest production. Meanwhile, 'Rubaru', 'Bauji' and 'Tuk Tuk' varieties seemed to have similarities in their chlorophyll content. Shallot has higher chlorophyll a than chlorophyll b. The chlorophyll a of shallot leaf is two to three times higher than chlorophyll b. There are several photosynthetic pigments in a plant leaf. Chlorophyll a and chlorophyll $\mathrm{b}$ are considered as light energy collectors, while other pigments such as carotenoid and anthocyanin are more related to photoprotection. Chlorophyll a is the main or primary photosynthetic pigment, while chlorophyll $\mathrm{b}$ is more like an accessory pigment passing the light energy to chlorophyll a. Chlorophyll could be reduced in term to prevent damage in photosynthetic apparatus, for example, allowing the low light to be absorbed (Viljevac et al., 2013).

Anthocyanin protects the plant leaf, especially from solar exposure and ultraviolet radiation. Anthocyanin is one of the essential phenolic com- pounds synthesized through the flavonoid pathway. It is mainly related to the red color in leaf or fruit (He et al., 2010). The observation showed that 'Palasa' variety had a higher anthocyanin content compared to other varieties at 20 DAP. At 30 DAP, there were no significant differences between the varieties in the anthocyanin content, ranging from 0.023 to $0.027 \mathrm{mg} \mathrm{g}-1$ on fresh wet basis, while at 40 DAP, 'Bauji' variety had the highest anthocyanin, and 'Bantaeng' variety had the lowest one. The content of anthocyanin in 'Bauji' variety was twice higher compared to that observed at 30 DAP (Table 1).

The fluctuation of anthocyanin content in leaf might be caused by the change or fluctuation of environmental situations during cultivation ( $\mathrm{He}$ et al., 2010). These environmental changes could be responded differently by different varieties of the same species due to the different content of leaf anthocyanin (Muhidin et al., 2018). The high content of anthocyanin in the leaf could be inferred as hexose aggregation reduction that might obstruct the early senescence caused by sugar as one mechanism to anticipated senescence (Piccolo et al., 2018).

Carotenoid is leaf pigment, which is also crucial for the plant life cycle. Carotenoid also has a function to protect the leaf mainly from excess light. Different harvesting periods could result in the different content of carotenoid. The environment condition, such as drought and shade might also be related to the fluctuation of carotenoid concentration in leaf (D'angiolillo et al., 2018). 'Palasa' variety still had the highest carotenoid content compared to Bauji, 'Tuk Tuk', 'Rubaru', and 'Palasa' in all observation time even though there was fluctuation between the varieties. There were no significant differences between Bauji, 'Bantaeng', 'Tuk Tuk' and 'Rubaru' in carotenoid content at three times observation. The differences in leaf 
pigments content between varieties within a species can illustrate the differences in eco-physiological responses. Those could be related to the capacity of plants to carry out photosynthesis.

At 30 DAP, the green part of the plant leaves was taken to check the tissue nutrient content (Figure 2). Leaf has several functions as a place to conduct photosynthesis and respiration, as well as to accumulate nutrients from the external environment. According to Figure 2, 'Bantaeng' variety had the highest total nitrogen, while 'Palasa' had the lowest one, which was $18.63 \%$ lower than that of 'Bantaeng' variety. 'Bantaeng' variety also had the highest phosphorus content, while the lowest one was observed in to ;Bauji' variety, which was $29.39 \%$ lower than that of 'Bantaeng' variety. 'Bauji' variety had the highest potassium content, but it was not significantly different from that of 'Bantaeng' variety. 'Palasa' variety had the lowest potassium content, which was $29.39 \%$ lower than that of 'Bauji' variety. Meanwhile, 'Palasa' variety had the highest total sulfur compared to other varieties.

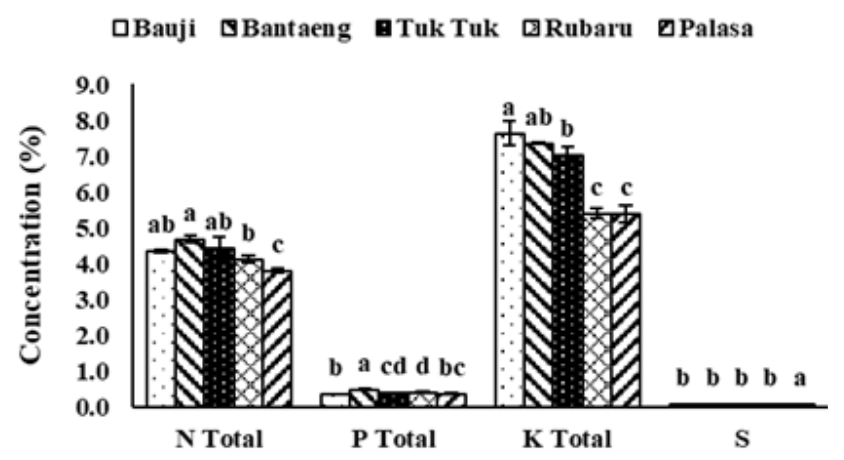

figure 2. Total nitrogen, total phosphorus, total potassium and total sulfur of five varieties at $30 \mathrm{DAP}$

Shallot plants need enough nutrients to grow well. Some essential elements that are generally needed by onion family plants include nitrogen, phosphorus, potassium, and sulfur. Nitrogen and phosphorous are essential for leafy vegetables. It is vital for leaf growth and development and for plants to have pleasant leaf greenness. Besides for leaf growth, phosphorous is also vital for the root growth. Phosphorus is not easily lost and is usually available in adequate quantities in the soil. Potassium increases the ability of plants to resist disease attacks and damage due to cold temperatures. Meanwhile, sulfur is a crucial element for onions because sulfur is also needed by onions to form proteins. Sulfur is vital for the formation of scents in onions and improving bulb quality (Boyhand et al., 2009).

Based on the analysis of the leaf tissue nutrient, 'Bantaeng' variety had a higher leaf nutrient concentration compared to other varieties. The higher capability to accumulate more nutrients is in line with the plant photosynthesis performance. The ability of leaf tissue to accumulate photosynthesis products and nutrients is usually identical to the size of the tissue. Internal allocation of leaves, both for photosynthesis results and nutrients, will commonly accelerate the rate of plant growth (White et al., 2016)

Some studies show that there is a correlation between the leaf nutrient content and the plant leaf pigment concentration. The addition of fertilizer that contains high nitrogen is assumed to increase the leaf greenness. The leaf nutrient status becomes crucial in assessing plant photosynthesis performance. In this experiment, the high performance of photosynthesis was not always related to the high pigment concentration. Different varieties could have different leaf nutrient status even they got the same amount of fertilizer. This result was in line with research on wheat and citrus, reporting that when several varieties of wheat were given fertilizer in the same amount, the varieties showed the different nitrogen content in their leaf tissues (Bojovic and Markovic, 2009; Gogoi and Basumatary, 2018).

Different varieties of shallot showed different fluctuation of phenolic content in green shallot in the three times observation (Figure 3). Total 


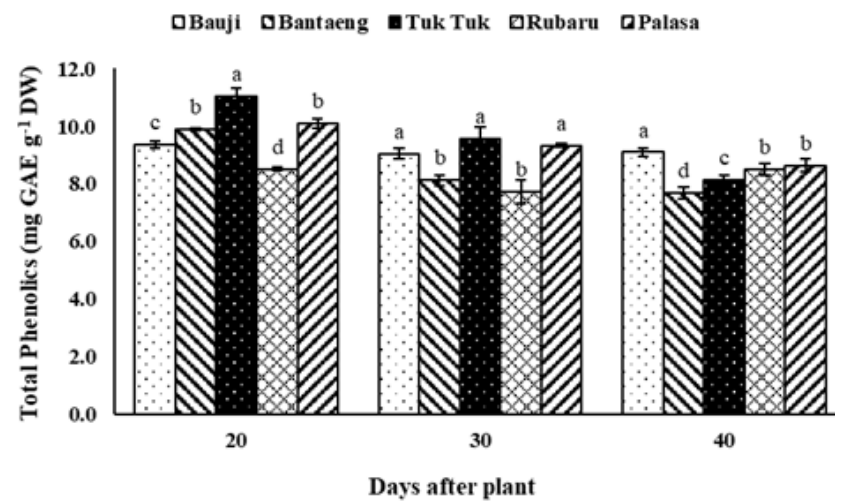

Figure 3. Total phenolic content of five shallot varieties at 20 , 30 and 40 DAP

phenolic content tends to decrease along with the increasing age of the plant. At 20 and 30 DAP, 'Tuk Tuk' variety had the highest phenolic content, while at 40 DAP, 'Bauji' variety had the highest total phenolic content. The highest total phenolic content was observed in 'Tuk Tuk' variety at 20 DAP, which then decreased by 7.45 $\%$ at 30 DAP. The total phenolic content of 'Bantaeng' variety, which had the highest production of green shallot, also decreased by $17.86 \%$ at 30 DAP, which continued to decrease by $5.37 \%$ at 40 DAP. Meanwhile, the total phenolic content of 'Palasa' variety, which had the lowest production, decreased by $7.57 \%$ and $7.41 \%$ at 30 and 40 DAP, respectively. Leaf has a different expression of total phenolic content compared to other parts of the plant. Phenolic compounds are groups of compounds with $\geq 1$ aromatic ring or $\geq 1$ hydroxy group. Phenolic compounds are classified into subgroups of phenol acids, flavonoids, stilbenes, coumarin, and tannins. As one of the secondary metabolite products in plants, it plays a vital role in plant reproduction, growth, and metabolism. It is also crucial in plant defense mechanisms against predators, viruses, bacteria, and fungi, as well as in contributing to plant color. Older leaf mostly has lower total phenolic content from the younger leaf. The fluctuation of phenolic compounds in plant leaf is influenced by the phenolic composition and the plant reaction to the environmental changes in the growing area. The characteristic of the variety also regulates the dynamic of phenolic compound accumulation. The elevated temperature and water condition of planting media are also driving the phenolic fluctuation as its role in the various aspect of the plant life cycle (Nasr et al., 2014).

The principal component analysis (PCA) was applied on the data obtained at 30 DAP (maximum vegetative) (Fig 4.a). According to the PCA result, there are only two principal components (PC) from this experiment. It is known from the eigenvalue, which is greater than 1.0, which is a common rule called as Kaiser-Guttman criterion (Matsunaga, 2010). The eigenvalue of the first principal component is 7.472 , while the second principal component is 2.437 . The biplot diagram of PCA performs that the combination of the first and the second principal component explains 90.09\% of total data variance in this experiment. The first principal component itself shows $67.93 \%$ of the total data variance, while the second principal component shows $22.16 \%$ of the total data variance. Parameters that support the principal component analysis could be identified from the loading factor value. This loading factors could be used to cut off the parameters that do not contribute to the PC. The parameters items are retained when the loading factor is greater than 0.5 to 0.6 (Matsunaga, 2010). The parameters contributing to the first PC are chlorophyll a, chlorophyll b, total chlorophyll, carotenoid, total phenolic, and total sulfur. In contrast, parameters that contribute to the second PC are production, anthocyanin and total phosphorous.

PCA also performs the relationships between the parameters. The close related parameters could be seen from its position on the diagram, which comes from the correlation from those parameters. The biplot diagram shows that chlorophyll a, chlo- 


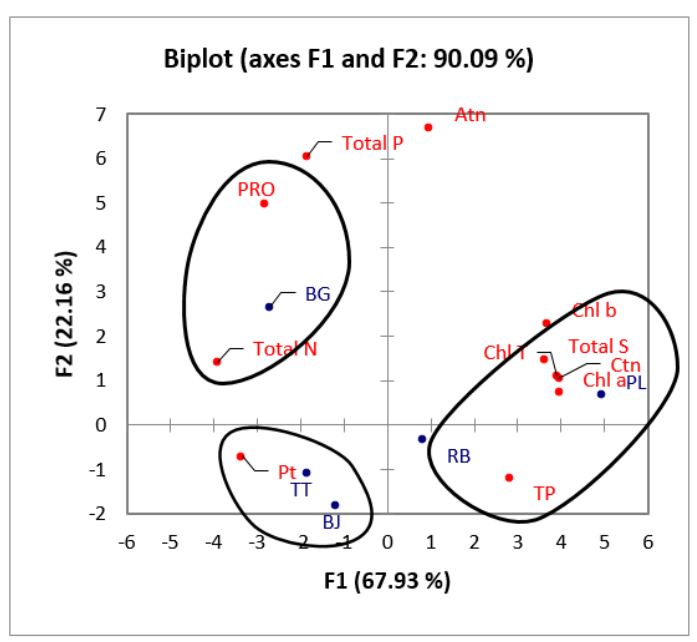

(a)

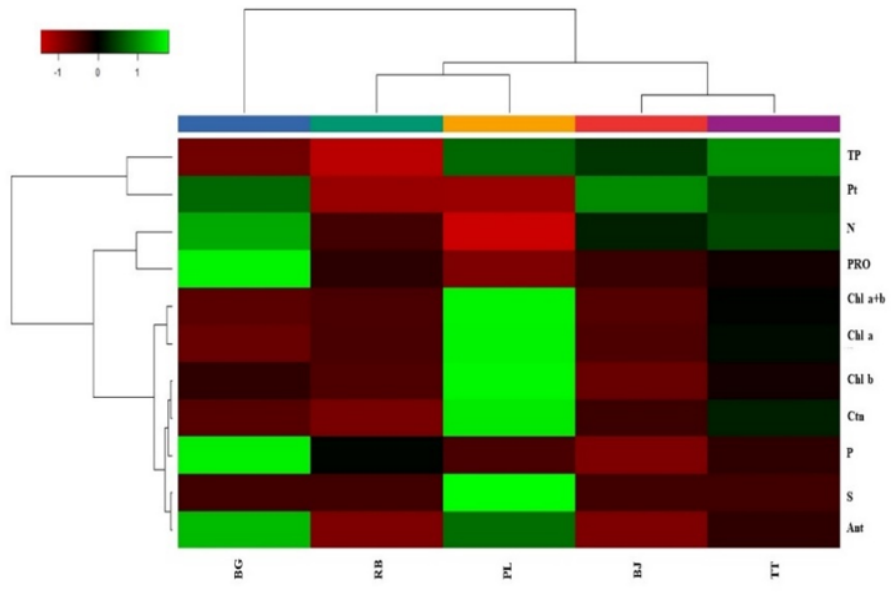

(b)

Remarks:

-TP: Total Phenol

-Pt: total potasium

- $\mathrm{N}$ : total nitrogen

-P: total phosporous

-PRO: Production

-BJ: 'Bauji'

-BG: 'Bantaeng'

- TT: 'Tuk Tuk'

-RB: 'Rubaru'

-PL: 'Palasa'

Figure 4. Principal component analysis (PCA) (a) and hierarchical heat map of five shallot varieties and observation parameters (b)

rophyll b, total S, and carotenoid have a relatively on the opposite axis from 'Palasa' and 'Bantaeng' close relation, while anthocyanin is not related varieties. The third cluster is 'Bantaeng', based on to those parameters. The high content of total nitrogen and total phosphorus is related to the high production of 'Bantaeng' variety. Converely, total nitrogen and production have a negative correlation with chlorophyll a, chlorophyll b, total chlorophyll, total S, and carotenoid content, while anthocyanin is not related to those parameters. the first axis of the principal component, which is located opposite 'Palasa'. 'Bantaeng' is supported by parameters value as total nitrogen, total phosphorous, and production.

The hierarchical heat map shows that 'Bantaeng' variety is different compared to 'Rubaru', 'Tuk Tuk', 'Bauji', and 'Palasa' varieties. 'Rubaru'

'Palasa' variety had the highest chlorophyll and sulfur content. On the contrary, it had the lowest production compared to other varieties used in this experiment. From PCA, we can also cluster the varieties based on the overview parameters in two principal components. The first cluster is 'Palasa' and 'Rubaru' varieties supported by the content of chlorophyll a, chlorophyll a, total chlorophyll, total sulfur, and carotenoid based on the first principal component. The second cluster is 'Tuk Tuk' and Bauji varieties, which seem to have a similar chemical character based on the diagram of the second principal component. Those varieties are located variety has more similarity to 'Palasa' variety, while 'Bauji' variety has a similar character to that of 'Tuk Tuk' variety. Total phenolic content, total potassium, total nitrogen, and production have a significant influence on the clustering parameters for the group of shallots at 30 DAP. Focusing on production, 'Bantaeng' cultivar, which had the highest production, also had the highest nitrogen and phosphorous content in its leaf, but it had the lowest chlorophyll content. In the opposite of 'Bantaeng' variety, 'Palasa' variety, which had the lowest production, had the highest chlorophyll and sulfur content. 
Shallot varieties used in this experiment were collected from different area. It is possible to have different production and pigment content when the varieties are planted in one homogenous planting technique. The previous local adaptability and the genotype composition among the varieties significantly showed the different responses in its interaction with the growing environment. The varieties performance in production and its chemical leaf content could be used as a reference to choose the best varieties that have a better quality as leafy vegetables for consumption (Sari et al., 2017). Further information concerning the various chemical contents in green shallots needs to be observed to get a broader perspective as an alternative to the utilization of shallots. 'Bantaeng' variety might have the highest production. However, it generally has the low pigment content in its leaf. Meanhwile, 'Palasa' variety had higher pigment content but the lowest production. The low pigment content in 'Bantaeng' variety manifests its effectiveness in photosynthesis performance viewed from the production side. Photosynthesis is not only related to the leaf photosynthesis pigment but also related to many other factors such as nutrient absorption and storage capacity for both photosynthetic and nutrient products (Chikov, 2017). The source and sink relationship in 'Bantaeng' variety could be one of the crucial genetic traits that distinguish it from other varieties. Total phenolics content of five varieties of green shallot varied from 7.71 to 11.03 mg GAE g-1 DW or 0.65 to 0.97 mg GAE g-1 FW. This means that green shallot could be consumed as one of phenolic content resources in human diets where the average need of phenolic content for adult is $2196 \mathrm{mg}$ per person per day (Goñi and Hernández-Galiot, 2019)

\section{CONCLUSION}

'Palasa' variety had the highest pigment content compared to other varieties. Total phenolic content fluctuated and varied between the five varieties in all observation times. Harvest time caused a change in pigment, total phenolic content, and leaf production in all varieties. The high pigment and phenolic content in the leaf were not in line with the high production of shallot leaf. PCA and hierarchical heat maps show that the varieties can be divided into three clusters. 'Bantaeng' variety had the highest leaf productions, and 'Tuk Tuk' variety had the highest total phenolic content.

\section{Acknowledgment}

The authors would like to thank the Endowment Fund for Education (LPDP), Ministry of Finance Republic of Indonesia for funding support in financing this research.

\section{REFERENCES}

Balitbangtan, [Badan Penelitian dan Pengembangan Pertanian]. (2007). Prospek dan Arah Pengembangan Agribisnis Bawang Merah. Jakarta Selatan: Kementerian Pertanian.

Balitbangtan, [Badan Penelitian dan Pengembangan Pertanian]. (2015). Inovasi Hortikultura Pengungkit Peningkatan PenDAPatan Rakyat (I. Djatnika, M. J. A. Syah, D. Widiastoety, M. P. Yufdy, S. Prabawati, S. Pratikno, \& O. Luthfiyah, Eds.). Jakarta Selatan: IAAR Press.

Baswarsiati, Sudaryono, T., Andri, K. B., \& Purnomo, S. (2015). Pengembangan Varietas Bawang Merah Potensial dari Jawa Timur. Retrieved from http://hortikultura.litbang.pertanian. go.id/Buku_Inovasi/5-20.Baswarsiati Pengembangan bawang merah.pdf

Bojovic, B., \& Markovic, A. (2009). Correlation between nitrogen and chlorophyll content in wheat ( Triticum aestivum L .). Kragujevac J, 31, 69-74.

Boyhand, G. E., Grandberry, D. M., \& Kelley, W. T. (2009). Green Onions Commercial Vegetable Production. Retrieved from https:// athenaeum.libs.uga.edu/bitstream/handle/10724/12353/ C821.pdf? sequence $=1$ \&isAllowed $=y$

Brasileiro, B. G., Leite, J. P. V., Casali, V. W. D., Pizziolo, V. R., \& Coelho, O. G. L. (2015). Acta Scientiarum The influence of planting and harvesting times on the total phenolic content and antioxidant activity of Talinum triangulare ( Jacq .) Willd. Acta Scientiarum: Agronomy, 37(2), 249-255. 
Chikov, V. I. (2017). The role of source-sink relations between photosynthetic and assimilate-consuming organs in regulation of plant photosynthesis. Agri Res \& Tech, 5(2), 1-11.

D'angiolillo, F., Mammano, michele massimo, \& Fascella, G. (2018). Pigments, polyphenols and antioxidant activity of leaf extracts from four wild rose species grown in Sicily. Not Bot Horti Agrobo, 46(2), 402-409.

Dharma, I. P. (2016). Mengkaji hasil daun bawang merah pada jarak tanam berbeda. Retrieved from https://simdos.unud.ac.id/ uploads/file_penelitian_1_dir/0f7d17659158a0e80f17302 29dd5c690.pdf

El-Hamd, A. A. S. A., Mohamed, A. A. M., \& El-din, M. G. Z. (2016). Effect of some Agricultural Treatments on Productivity and Quality of Green Onion for Export ( Allium Cepa L ). Middle East Journal of Agriculture Research, 5(1), 37-44.

Eviati, \& Sulaeman. (2009). Analisis Kimia Tanah, Tanaman, Air, dan Pupuk. Balai Penelitian Tanah.

Fuentealba, C., Quesille-villalobos, A. M., González-muñoz, A., Torrico, J. S., Shetty, K., Ranilla, L. G., ... González-muñoz, A. (2017). Optimized methodology for the extraction of free and bound phenolic acids from Chilean Cristalino corn (Zea mays L .) accession. CyTA - Journal of Food, 15(1), 91-98.

Gogoi, M., \& Basumatary, M. (2018). Estimation of the chlorophyll concentration in seven Citrus species of Kokrajhar district , BTAD , Assam , India. Tropical Plant Research, 5(1), 83-87.

Goñi, I., \& Hernández-Galiot, A. (2019). Intake of nutrient and nonnutrient dietary antioxidants. contribution of macromolecular antioxidant polyphenols in an elderly mediterranean population. Nutrients, 11, 2-11.

Gutiérrez-Grijalva, E. P., Ambriz-Pére, D. L., Leyva-López, N., CastilloLópez, R. I., \& Heredia, J. B. (2016). Review: dietary phenolic compounds, health benefits and bioaccessibility. Archivos Latinoamericanos De Nutricion, 66(2), 87-100.

He, F., Mu, K., Yan, G. liang, Liang, N. N., Pan, Q. H., Wang, J., ... Duan, C. Q. (2010). Biosynthesis of anthocyanins and their regulation in colored grapes. Molecules, 15, 9057-9091.

Kamble, P. N., Giri, S. P., Mane, R. S., \& Tiwana, A. (2015). Estimation of chlorophyll content in young and adult leaves of some selected plants. Universal Journal of Environmental Research and Technology, 5(6), 306-310.

Kuai, B., Chen, J., \& Hörtensteiner, S. (2018). The biochemistry and molecular biology of chlorophyll breakdown. Journal of Experimental Botany, 69(4), 751-767.

Lombardo S, Pandino G, Mauromicale G (2018) The influence of preharvest factors on the quality of globe artichoke. Scientia Horticulturae 233:479-490. doi:10.1016/j.scienta.2017.12.036

Matsunaga, M. (2010). How to Factor-Analyze Your Data Right : Do's , Don'ts , and How-To's . International Journal of Psychological Research, 3(1), 97-110.

Muhidin, Syam'un, E., Kaimuddin, Musa, Y., Sadimantara, G., Usman, ... Rakian, T. (2018). The effect of shade on chlorophyll and anthocyanin content of upland red rice. International Conference on Agriculture, Environment and Food Security, 2-6.
Nasr, S. Ben, Aazza, S., Mnif, W., \& Miguel, M. (2014). Phenol content and antioxidant activity of different young and adult plant parts of tobacco from Tunisia, dried at 40 and 70 oC. Journal of Applied Pharmaceutical Science, 4(08), 23-31.

Pavlovic, D., Nikolić, B., Đurović, S., Waisi, H., Anđelković, A., \& Marisavljevic. (2014). Chlorophyll as a measure of plant health : agroecological aspects. Pestic. Phytomed, 29(1), 21-34.

Piccolo, E. Lo, Landi, M., Pellegrini, E., Agati, G., Giordano, C., Giordani, T., ... Massai, R. (2018). Multiple consequences induced by epidermally-located anthocyanins in young, mature and senescent leaves of Prunus. Frontiers in Plant Science, 9(917), 1-16.

Putri, F., Aziz, S. A., Andarwulan, N., \& Melati, M. (2020). Growth performance of green shallot from five different varieties in Indonesia. Plant Archives, 20, 813-818.

Ramya, V., \& Patel, P. (2019). Health benefits of vegetables. International Journal of Chemical Studies, 7(2), 82-87.

Sari, V., Miftahudin, \& Sobir. (2017). Keragaman genetik bawang merah (Allium cepa L .) berdasarkan marka morfologi dan ISSR. J. Agron. Indonesia, 45(2), 175-181.

Sekara, A., Pokluda, R., Vacchio, L. Del, Somma, S., \& Caruso, G. (2017). Interactions among genotype, environment and agronomic practices on production and quality of storage onion (Allium cepa L.) - A review. Hort. Sci. (Prague), 44(1), 21-42.

Sims, D., \& Gamon, J. (2002). Relationship between leaf pigment con- tent and spectral reflectance across a wide range species, leaf structures and development stages. Remote Sensing of Environment, 81, 337-354.

Upadhyay, R. K. (2018). Plant pigments as dietary anticancer agents. International Journal of Green Pharmacy, 12(1), 2-16.

Viljevac, M., Dugalic, K., Mihaljevic, I., Simic, D., Sudar, R., Jurkovic, Z., \& Lepedus, H. (2013). Chlorophyll content, photosynthetic efficiency and genetic markers in two sour cherry ( Prunus cerasus L .) genotypes under drought stress. Acta Bot. Croat, 72(2), 221-235.

White, A. C., Rogers, A., Rees, M., \& Osborne, C. P. (2016). How can we make plants grow faster? A source - sink perspective on growth rate. Journal of Experimental Botany, 67(1), 31-45. 